Western University Scholarship@Western

Centre for the Study of International Economic

Centre for the Study of International Economic

Relations Working Papers

Relations

1987

\title{
Capital, Skills, and International Trade
}

Ian Wooton

Follow this and additional works at: https://ir.lib.uwo.ca/economicscsier_wp

Part of the Economics Commons

Citation of this paper:

Wooton, Ian. "Capital, Skills, and International Trade." Centre for the Study of International Economic Relations Working Papers, 8702C. London, ON: Department of Economics, University of Western Ontario (1987). 
ISSN $\quad 0228-4235$

ISBN $\quad 0-7714-0827-7$

THE CENTRE FOR THE STUDY OF INTERNATIONAL ECONOMIC RELATIONS

WORKING PAPER $8702 \mathrm{C}$

CAPITAL, SKILLS, AND INTERNATIONAL TRADE

Ian Wooton

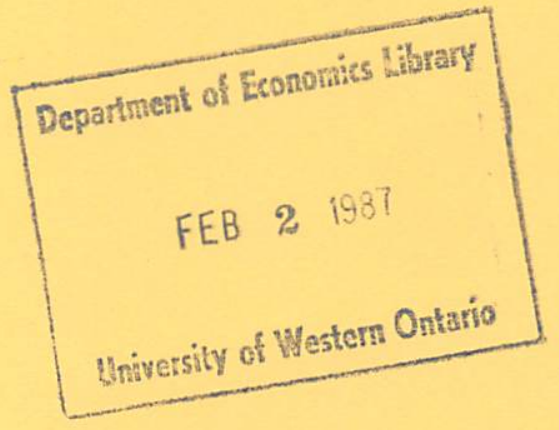

This paper contains preliminary findings from research work still in progress and should not be quoted without prior approval of the authors.

DEPARTMENT OF ECONOMICS

THE UNIVERSITY OF WESTERN ONTARIO

LONDON, CANADA

N6A 5 C2 
CAPITAL, SKILLS, AND INTERNATIONAL TRADE

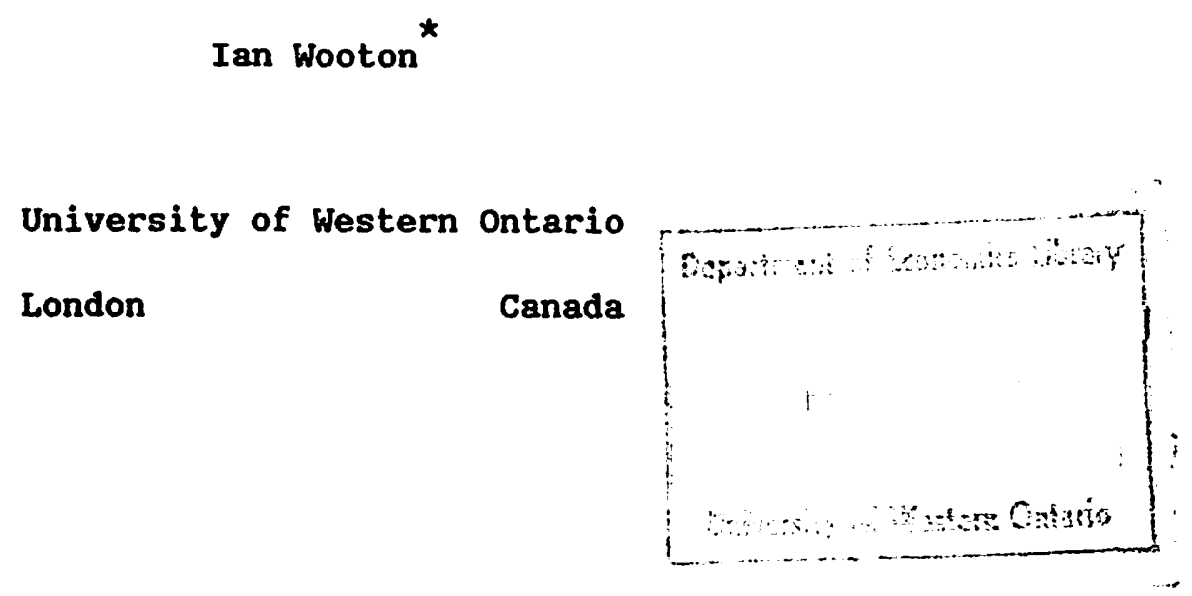

Abstract

This paper examines the decisions made by agents of countries as to their levels of education and physical capital accumulation and the consequent pattern of world trade. The major elements influencing these decisions are the rates of physical capital depreciation and of population growth. Countries whose capital depreciates quickly or whose populations expand rapidly will invest less in education and in acquiring physical capital. Stylized facts that high population growth countries will be relatively poorer, less well educated, and will face a secular deterioration in their terms of trade are confirmed.

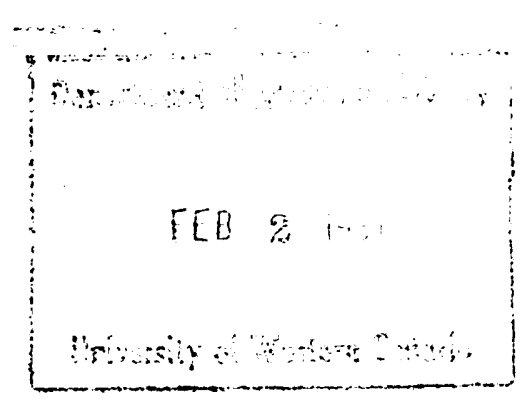




\section{Introduction}

In a recent paper, Dinopoulos and Wooton (1986) introduce human capital accumulation into the standard, two-sector, general equilibrium model of international trade. Agents in the economy were endowed with their own labour power together with an exogenously determined amount of physical capital. Rather than using these endowments directly in the production process, the agents had the opportunity to use some of the capital in an educational sector, raising the effective size of the labour force through enhancing workers' skills. Thus, education became a conduit through which agents could convert the labour and capital stocks actually used in final goods production from the levels initially endowed to a country.

While Dinopoulos and Wooton (1986) sheds light on the potential for substitution between physical and human capital, it is still essentially an endowment model, albeit in a dynamic setting. Physical capital is not produced nor does it depreciate over time. Given that the trade patterns that result from the model depend on the relative endowments of capital and labour between countries, it seems appropriate that the process of physical capital accumulation be more closely examined. This paper is an attempt to do precisely that.

As in Dinopoulos and Wooton (1986), an overlapping generations model of international trade is adopted in which countries have an education sector and a manufacturing sector. In this paper, instead of two consumption goods being produced, physical capital is produced together with a single consumption good. Agents optimize over their lifetimes in their choice of investment in both physical and human capital. A credit market exists that permits agents 
to borrow for consumption and investment expenditures that exceed the same period's income, the interest rate being determined endogenously through the requirement that the credit market clears.

In section 2, the model is set out, while section 3 determines the steady-state equilibrium for a country in autarky. Section 4 introduces international trade to a "small" country, with "large-country" effects being determined in section 5 . The model is applied to trade between countries with different rates of population growth in section 6 , and the paper concludes with a summary of the results.

\section{The Lodel}

Consider an economy that, at any period in time, is composed of two generations of agents. Each agent lives two periods then dies, to be replaced by a newly-born agent. In each period of life, an agent consumes some of the consumer good $(Y)$, that is produced by the economy together with a capital good (X). In the first period, agents (termed "students") also acquire skills through the purchase of educational services and invest in physical capital to use in the following period's production. In the second and final period of their lives, agents (now termed "workers") apply their skills and capital in the economy's manufacturing processes. 1

The quantity of labour services available for use in production in any period depends upon the quantities of education purchased by workers in the period in which they were students. Let

$$
E^{t}=H\left[R_{E}^{t}, N^{t}\right]
$$


where $B^{t}$ is the quantity of skills acquired by students of generation $t$ (that is, born in period $t$ ) and $k_{B}^{t}$ is the quantity of capital used in its provision. $N^{t}$ is the number of students of generation $t$ : initially it will be assumed that $\mathrm{s}^{\mathrm{t}}$ is constant over time, and so the population of the economy remains constant. It is assumed that the function $H$ is linearly homogeneous in its arguments, with positive first partial derivatives and negative second partial derivatives. Thus equation (1) may be rewritten as:

$$
e^{t}=E^{t} / N^{t}=H\left[k_{B}^{t}, 1\right]=h\left[k_{B}^{t}\right] \text {. }
$$

where $k_{B}^{t}$ is the quantity of capital services used in education per student, that is,

$$
k_{B}^{t}=k_{B}^{t} / N^{t}
$$

and, taking derivatives with respect to capital,

$$
h \cdot\left[k_{E}^{t}\right]=H_{K}\left[K_{E}^{t}, N^{t}\right]
$$

The total quantity of labour services an individual worker can offer is defined as the sum of "natural" ability (with which the worker was born or acquires in youth without the aid of formal education--equal to unity) and the quantity of education undergone. Thus the effective labour supply (measured in efficiency units) in period $t$ is determined both by the size of the previous period's educational input and by the number of agents born in generation $(t-1)$ :

$$
L^{t}=\left(1+e^{t-1}\right) N^{t-1}=E^{t-1}+N^{t-1} .
$$


Physical capital is identical to good $X$. Students may acquire the capital, to be used in production together with their labour services, either through purchasing the stocks of the older generation or by investing in quantities of newly-produced good $X$. Capital which is used in production is assumed to depreciate at rate $\delta$ per period. The capital stock purchased by generation $(t-1)$ for use in period $t$ is then

$$
k^{t}=(1-\delta) k^{t-1}+I^{t-1}
$$

where $I^{t-1}$ is the quantity of new capital bought by generation $(t-1)$. The capital available for use in goods manufacturing is then

$$
K_{M}^{t}=K^{t}-K_{B}^{t}
$$

Production of goods $X$ and $Y$ is according to production functions exhibiting constant returns to scale:

$$
\begin{aligned}
& X^{t}=F\left[K_{X}^{t}, L_{X}^{t}\right] \\
& Y^{t}=G\left[K_{Y}^{t}, L_{Y}^{t}\right]
\end{aligned}
$$

where:

$$
\begin{aligned}
& K_{X}^{t}+K_{Y}^{t}=x_{Y}^{t} \\
& L_{X}^{t}+L_{Y}^{t}=L^{t}
\end{aligned}
$$


The supply of labour in period $t$ can never be less than $w^{t-1}$. The maximum quantity of labour would result from all capital in period ( $t-1)$ having been employed in education i.e.,

$$
\mathrm{L}_{\max }^{t}=H\left[K^{t-1}, \mathrm{~N}^{t-1}\right]+\mathrm{N}^{t-1}
$$

In equilibrium, $\mathrm{L}^{t}<\mathrm{L}_{\max }^{t}$, given the necessity for non-zero inputs of both capital and labour into the production of consumption goods. Equations (6) and (7) can be rewritten as:

$$
\begin{aligned}
& X^{t}=L_{X}^{t} f\left[k_{X}^{t}\right] \\
& Y^{t}=L_{Y}^{t} g\left[k_{Y}^{t}\right]
\end{aligned}
$$

where

$$
k_{X}^{t}=k_{X}^{t} / L_{X}^{t}, \quad k_{Y}^{t}=k_{Y}^{t} / L_{Y}^{t} .
$$

and the functions $f$ and $g$ have positive first and negative second derivatives. Agents maximize their lifetime utilities through their intertemporal consumption choice and their decisions on investment in both human and physical capital. Assume that the utility function is time separable, such that the lifetime utility of an individual of generation $t$ is:

$$
u^{t}=u\left[c^{t 1}\right]+\frac{1}{1+\rho} u\left[c^{t 2}\right]
$$

where $p$ is the rate of discount on future consumption and $c^{t i}$ is the consumption of good $Y$ in the $i^{\text {th }}$ period of life by an agent of generation $t$. 
In order for individuals to be able to consume while they are students and have no income, there has to be a mechanism for the provision of loans, repayable by them in their second period. Now, they cannot borrow from workers in the previous generation as those agents will die before being repaid. Assume, therefore, that these loans are made in the form of real bonds by the government of the country. The important attribute of the government is its infinite life, enabling it to facilitate intertemporal transfers between agents. In period $t$, the supply of loanable funds is equal to the repayments of debt incurred in the previous period by agents of generation $t-1$. These funds are lent to agents of generation $t$ by the government, which charges interest at the market-clearing rate of $R^{t}$ per period on the principal. Thus the government has zero net worth. 2

Suppose that the relative price of the two manufactured goods in the economy in period $t$ is:

$$
p^{t}=P_{Y}^{t} / P_{X}^{t}
$$

If the country is diversified in its production of goods (which will necessarily be the case in autarky), this price will determine the relative capital intensities in production and the returns to the factors of production. Assume that, at any relative price, the production of the capital good, $X$, is intensive in its use of capital relative to the production of the consumer good, $Y$. The return to capital in the educational sector must equal that in manufacturing, while factor mobility will also ensure that the wage rates in $X$ and $Y$ production are equalized. Thus:

$$
f \cdot\left[k_{X}^{t}\right]=p^{t} \cdot\left[k_{Y}^{t}\right]=q^{t} \cdot\left[k_{E}^{t}\right]=r^{t}
$$




$$
\left(f\left[k_{X}^{t}\right]-f \cdot\left[k_{X}^{t}\right] k_{X}^{t}\right)=p^{t}\left(g\left[k_{Y}^{t}\right]-g^{\prime}\left[k_{Y}^{t}\right] k_{Y}^{t}\right)=w^{t}
$$

where $q^{t}$ is the relative price of education in terms of $\operatorname{good} X$,

$$
q^{t}=P_{E}^{t} / p_{X}^{t}
$$

and $f^{\prime}$ and $g^{\prime}$ represent the first derivatives of the corresponding production functions. Students do not buy education directly, as it is a product partly of their own effort. Instead, the students hire capital services which are combined with their efforts in producing skilled labour.

Domestic demand for goods and types of capital, as well as the allocation of these resources, may be determined by maximizing the representative agent's lifetime utility which, due to the assumptions of identical agents and homogeneity in production and utility, is the same as maximizing the utility of a generation. Thus maximize equation (10) subject to:

$$
\begin{aligned}
& p^{t} c^{t 1}+r^{t} k_{B}^{t}+k^{t+1}=b^{t} \\
& p^{t+1} c^{t 2}+\left(1+R^{t}\right) b^{t}=w^{t+1}\left(1+h\left[k_{E}^{t}\right]\right)+r^{t+1} k^{t+1}+(1-\delta) k^{t+1}
\end{aligned}
$$

where $b^{t}$ is the borrowing made for period 1 consumption (a bond denominated in units of good $X$ ) and $k^{t+1}$ is the capital holding per agent of generation t. i.e.

$$
k^{t+1}=x^{t+1} / x^{t} .
$$


First-order conditions yield:

$$
\begin{aligned}
& \frac{u^{\prime}\left[c^{t 2}\right]}{u^{\prime}\left[c^{t 1}\right]}=\frac{p^{t+1}(1+p)}{p^{t}\left(1+R^{t}\right)} \\
& R^{t}=r^{t+1}-\delta \\
& \frac{h^{\prime}\left[k_{E}^{t}\right] w^{t+1}}{\left(1+R^{t}\right)}=r^{t}
\end{aligned}
$$

Equation (17) yields the allocation of expenditure over the two periods of an agent's lifetime. Were $R=\rho$, the market rate of interest being equal to the private rate of discount, and were relative prices to remain constant over time, then the agent would consume the same quantity of $X$ as a student and as a worker. From (18), the cost of a unit of capital (the interest paid on borrowing) must in equilibrium equal the net return on that unit--its marginal productivity less the depreciation of the capital through its use in production. In equation (19), capital invested in education raises the size of the following period's workforce. The present value of this investment is then the induced increase in the stock of labour times its marginal product (the wage rate) discounted to the present. In equilibrium, this benefit is exactly offset by the cost--the loss in current production from the removal of the physical capital. 3

For a given market rate of interest, the capital invested in each student is a function of the relative returns to capital and to labour, which are themselves functions of the commodity price ratios in the two periods of the student's life (on the assumption that the country is producing both good $X$ and $\operatorname{good} Y$ ). Thus the level of education acquired by each agent in the 
economy is a function of the price ratios and the market rate of interest. It was shown in Dinopoulos and Wooton (1986) that, in a model with fixed capital endowments, the level of education undertaken by countries is independent of those endowments and that trade between countries with identical technologies results in agents of both countries acquiring the same level of individual education.

\section{The Autarkic steady state}

Suppose that the economy does not trade with any other country. Thus, agents consume only what is produced in the country itself. Both $x$, the capital good) and $Y$ (the consumption good) will be in demand and must then be domestically produced. In addition, assume that the population of the economy is constant, the same number of agents being born to each generation. In the steady state, with unchanging population, all variables are constant and, therefore, all time superscripts may be eliminated from the equations. The optimal allocation between generations in a model with durable goods was shown by Diamond (1965) to be achieved by a rate of interest on borrowing equal to the rate of population growth. Using Samuelson's (1958) terminology, the "biological market interest rate" in this case would be $R=0$ and, given the assumptions made here about the government, the prevailing interest rate charged will indeed be zero.

The rate at which physical capital depreciates in each period is determined by technology and therefore, in equation (19), capital must be acquired to the point that its rate of return equals the interest rate (zero) plus the rate of depreciation. Thus the steady-state rate of return on capital, $\tilde{\mathbf{r}}$, must equal $\delta$. As in the standard, two-good, two-factor model, 
there is a one-to-one relationship between the rate of return on capital and the relative price ratio of the goods. Hence the determination of $\tilde{r}$ also yields the equilibrium values of $p$ and $w$, as well as the capital-labour ratios used in the production of $X$ and $Y$. From equation (19), the investment in human capital can be determined and, using that result in equation ( 3 ), the size of the labour force is then known.

What about the quantity of physical capital employed in production? In the steady state, the per-capita holdings of capital remains constant over time, that is,

$$
x^{t}=x^{t-1}
$$

The economy, by virtue of having a constant capital-labour ratio for all time, is therefore on a golden-age path. Substituting this into equation (4) gives the steady-state level of investment in new capital as equal to the quantity of the existing capital stock that depreciates in any period:

$$
\mathbf{I}=\boldsymbol{\delta} \mathbf{K} \text {. }
$$

Substituting the zero rate of interest into equation (18), results in an equilibrium rate of return to capital equal to the rate of depreciation and hence, from equation (21),

$$
\mathbf{I}=\tilde{\mathbf{r}} \mathbf{K}
$$

the level of investment in physical capital in the economy is equal to the return on the steady-state capital stock. This is Phelps' "Golden Rule of Accumulation". Note then that all of the income generated by the physical capital stock is re-invested in order to offset the depreciation. Income for consumption is therefore provided by the earnings of labour. 
Combining the steady-state variants of equations (15) for all agents in the economy, and letting $R=0$, yields the country's income-expenditure equation:

$$
p[\tilde{r}] C+\tilde{r} K_{E}+I=w[\tilde{r}](N+E)+\tilde{r} K
$$

where $C$ is the total consumption of good $Y$ by agents of the two extant generations. Substituting equations (19) and (22) into equation (23), and using Euler's Theorem results in:

$$
p[\tilde{r}] C=w[\tilde{r}]\left(1+H_{N}\right) N
$$

where $H_{N}$ is the marginal productivity of students in acquiring their skills which is an increasing function of the per capita investment of capital in education. The income for consumption expenditures is derived from unskilled wage income together with the productivity of agents in increasing their skills through education.

What remains to be determined is the size of the steady-state capital stock. Now, in the closed economy, all additions to the capital stock must be domestically produced. Thus $I=X$, investment in capital equals the production of the capital good and hence, from equation (22), the demand for $X$ is equal to the return on capital holdings in the economy.

Figure 1 is drawn in factor space. There are oN agents in each generation. These agents acquire skills through the purchase of capital to use in education--transforming the capital into a larger workforce. The optimal allocation is at point $A$, tangent to the wage rental ratio $w[\tilde{r}] / \tilde{r}$, with a corresponding labour force of OD and an educational capital stock of OC. Line $\mathrm{BE}$ is an isocost curve at the prevailing price ratio (with slope equal to $w[\tilde{r}] / \tilde{r})$ that constitutes the net income of workers, after paying for 
their education, and is available to spend on the consumer good. The capital-labour ratios $k_{X}$ and $k_{Y}$ used in manufacturing are determined by the wage-rental ratio. Point $F$, the intersection of $k_{Y}$ with BE yields the allocation of factors to consumer goods production. The capital necessary to ensure full employment of the labour force in capital-goods production can be found by drawing a line with slope $k_{X}$ from $F$ to $H$. Thus the capital stock used in manufacturing is DH, while the total capital stock of the country is AH.

Output is determined entirely by technology--the production functions and the rate of physical capital depreciation. The only role played by consumer demand is in determining the allocation of consumption across the lifetimes of agents.

\section{The Small, Open Economy}

Suppose now that the country trades with the rest of the world at exogenously given terms of trade, $p^{*}$, that are expected to persist into the next period. Consider what will now constitute the economy's steady state. The first-order condition, equation (18), is not affected by a move to free trade and hence the steady state will continue to be characterized by the rate of return on capital equalling the rate of depreciation, $\tilde{\mathbf{r}}=\delta$. Were the (exogenously given) world relative price equal to that in autarky, then there would be no gains from trade and the country will remain in autarky. Should the terms of trade be different then the country will trade, but its manufacturing sector will no longer be diversified. 
Suppose that $p^{*}<p[\tilde{r}]$, the world relative price of $x$ is higher than the autarkic price. It will not be profit-maximizing for the home country to continue producing both goods and so it will specialize in the relatively higher-valued good, $X$. The steady-state rate of return on capital remains equal to $\delta$ and hence the capital-labour ratio used in the production of $x$ must remain the same as that in autarky. Similarly, the wage rate stays the same and, from equation (19), the amount of investment in human capital accumulation is unchanged. As a consequence, the size of the labour force does not alter. The impact on factor allocation is illustrated in Figure 1. All domestic goods production is concentrated on good $X$. As in autarky, the labour available for production is OD. With capital-labour ratio $k_{x}$, this requires a capital stock in manufacturing of DJ (greater than the DH required when production was diversified). Labour's net income is still represented by $B E$, but this now takes the form of goods of type $X$ that are traded for the consumption good $Y$. As $p *$ declines, production remains constant but the terms of trade of a country exporting $X$ improve and hence consumers gain in selling their fixed stocks of $X$ at better and better relative prices.

Suppose that $p^{*}>p[\tilde{r}]$. In this circumstance it is more profitable for the economy to specialize in the production of good $Y$. The actual production level will vary with the relative price $p^{*}$, which was not the case when only $x$ was being produced. The rate of return on capital must remain, in the golden-rule steady state, equal to $\delta$; thus

$$
\delta=p^{*} \mathbf{g}^{\cdot\left[k_{\mathbf{Y}}\right]}
$$


Totally differentiating equation (25) and rearranging,

$$
\frac{d k_{y}}{d p^{x}}=-\frac{g^{\prime}}{p^{\star} g^{\prime \prime}}>0 \text {. }
$$

the relatively cheaper that the capital good $(X)$ becomes, the relatively more capital-intensive domestic production becomes. Recall that

$$
p *\left(g\left[k_{Y}\right]-g^{\cdot}\left[k_{Y}\right] k_{Y}\right)=w .
$$

Differentiating and using equation (26) yields:

$$
\frac{d w}{d p^{\star}}=g\left[k_{Y}\right]
$$

The income, in terms of good $X$, accruing to workers increases with the relative price. (Clearly, the wage in terms of good $Y$ must also be increasing, as the capital intensity in production rises with increases in p*.) This increase in the wage rate influences the education decision, equation (19). Differentiating equation (19), letting $R=0$ and holding $r$ constant, results in

$$
\frac{d k_{E}}{d w}=-\frac{h^{\prime}\left[k_{E}\right]}{w^{\prime \prime}\left[k_{E}\right]}>0 .
$$

Thus,

$$
\frac{d k_{E}}{d p^{\star}}=-\frac{h^{\prime}\left[k_{E}\right] B\left[k_{Y}\right]}{w h^{\prime \prime}\left[k_{E}\right]}>0,
$$

as physical capital becomes relatively cheaper and the wage rate becomes relatively higher it is optimal to increase the investment in human capital. 
The wage-rental ratio also rises:

$$
\frac{d(w / r)}{d p^{\star}}=\frac{g\left[k_{Y}\right]}{p^{\star} g^{\prime}\left[k_{Y}\right]}>0 .
$$

These results are illustrated in Figure 2 . The increase in the wage-rental ratio induces increased educational investment, resulting in a larger workforce of $\mathrm{OR}$. The higher wage-rental ratio also causes more capital-intensive techniques to be used in production of $Y$, the capital-labour ratio rising to $k_{Y}^{\prime}$. The steady-state quantity of capital used in manufacturing has become RU (which may or may not be greater than the capital stock used when $\mathrm{X}$ was also produced) and the capital used in education has risen to RQ. The income of workers, to be allocated over the two periods of their lives, has definitely risen--their share of production now corresponds to the $Y$ isoquant passing through $T$, when previously it was to that passing through $F$.

The productive activity of the country corresponding to different steady-state world prices is shown in Figure 3 . AB has slope $1 / p[\tilde{r}]$. If $p^{*}=p[\tilde{r}]$, then the country would be diversified in its production. It could produce at any point on $A B$, but its consumption/investment point would have to be at $c$, the autarkic production point. For $p^{*}<p[\tilde{r}]$, the country would be completely specialized in $X$ production, producing at the $f$ ixed point $A$. Were $p^{\star}>p[\tilde{r}]$, then the country would specialize in the production of $Y$ and, as was shown above, the output of $Y$ would increase with its relative price as the economy accumulates more human and physical capital. 


\section{A Two-country Model}

Let the world be composed of two countries $A$ and B. These countries share the same technology for production and both have constant levels of population. The optimal market rate of interest in each would therefore be zero. The world capital market is not integrated: each country's government making domestic loans. The countries only differ in the rates at which capital depreciates: A having a lower rate of depreciation than $B$, that is

$$
\delta^{A}<\delta^{B}
$$

In autarky, each country would be diversified in goods manufacturing. The rate of return on physical capital in each would be determined by the respective rate of capital depreciation:

$$
\mathbf{r}^{A}=\delta^{A}<\mathbf{r}^{B}=\delta^{B} ;
$$

and these would determine the wage rates paid to each country's workers. Differentiating equation (19) to determine how the two countries' investments in human capital might differ yields

$$
\frac{d k_{E}}{d \delta}=\frac{\left(1-h^{\prime}\left[k_{E}\right] w^{\prime}[r]\right)}{h^{\prime \prime}\left[k_{E}\right] w[r]}<0 .
$$

As capital depreciates more rapidly, its rate of return (and hence cost) must rise in the steady state. As a consequence of this, the return to labour declines. Hence the cost of acquiring an education rises and the return to being educated diminishes with increasingly rapid capital depreciation reducing the incentive to learn. A's population will therefore be better educated than those in $B$.

The autarkic price ratios of the two countries also differ. Country B, having a higher rate of return on capital, will have a relatively high price for the capital-intensive good $X$, while the contrary will be true of country 
A. When the countries trade, the steady-state international price will 1ie between the two autarkic prices and so (remembering that $p$ is the relative price of $Y$ in terms of $X$ )

$$
\mathbf{p}^{\mathbf{A}}>\mathbf{p}^{*}>\mathbf{p}^{\mathbf{B}}
$$

Using the small country results of the previous section it can be determined that, at the common relative price of $p^{*}, A$ will specialize in the production of $\mathrm{X}$ while $\mathrm{B}$ will specialize in the production of $\mathrm{Y}$.

Thus differences amongst countries in the rates at which their capital depreciates will result in mutually beneficial international trade. The country whose capital lives longer (in the sense that it depreciates at the slower rate) will specialize in the production of the capital-intensive good (which may or may not be the capital good), while the other country will specialize in producing the good that requires a lower input of capital relative to labour. This pattern of specialization is generated by a different mechanism than that in stiglitz (1970). In that model, trade resulted from differences in rates of interest. Here, there is a common (biological) rate of interest: the difference between the two countries lies in their unequal rates of return to physical capital (due to different rates of depreciation).

\section{Growing Populations}

Now, let the population of an economy grow at a rate $n$, such that

$$
N^{t+1}=(1+n) N^{t}
$$

Consider, once again, the steady state of the autarkic economy in order to determine how investment in physical and human capital is influenced by the rate of population growth. In the steady-state, the physical capital stock 
wifl grow at the same rate as the labour force and therefore time superscripts may again be omitted.

Suppose the bond-issuing authority sets Samuelson's biological interest rate:

$$
\mathbf{R}=\mathbf{n} \text {. }
$$

Thus, the higher the rate of population expansion, the more costly borrowing becomes. The return to capital must no longer be just sufficient to offset its depreciation but must also be enough to pay the borrowing costs; that is, from equations (18) and (27),

$$
\mathbf{r}=\mathbf{n}+\boldsymbol{\delta}
$$

Making the appropriate substitutions into equation (19) yields a relationship between the rate of population growth and the per-capita investment of physical capital into education:

$$
\frac{h \cdot\left[k_{E}\right] w[n+\delta]}{(1+n)}=n+\delta
$$

Differentiating equation (29), and rearranging,

$$
\frac{d k_{E}}{d n}=\frac{1+2 n+\delta-\left(h^{\prime}\left[k_{E}\right] w^{\prime}[r]\right)}{h^{\prime \prime}\left[k_{E}\right] w[r]}<0
$$

The faster the labour force grows, the smaller the individual investment in human capital. This is a result, not only of the increased cost of borrowing, but also of the lower wage rate paid to workers.

The pattern of trade between two countries with populations growing at the same rate will still be determined by differences in their rates of physical capital depreciation, with the country whose capital depreciates the 
more rapidly exporting the labour-intensive commodity. Suppose, though, that one country's population were to grow at a faster rate than that of its trading partner. There then may no longer be a steady-state equilibrium, as the countries will be expanding differentially, but it is possible to examine how the pattern of trade would evolve over time.

Assume initially that agents are myopic with respect to prices, expecting current prices to persist into the next period (this assumption will be relaxed, below), and that country $A$ has a lower rate of capital depreciation than that of country $B$. The relative price at which countries are non-specialized in production is a function of the rate of return to capital, itself dependent on the sum of the rates of population growth and physical-capital depreciation. Five outcomes are possible, shown in Table 1. TABLE 1

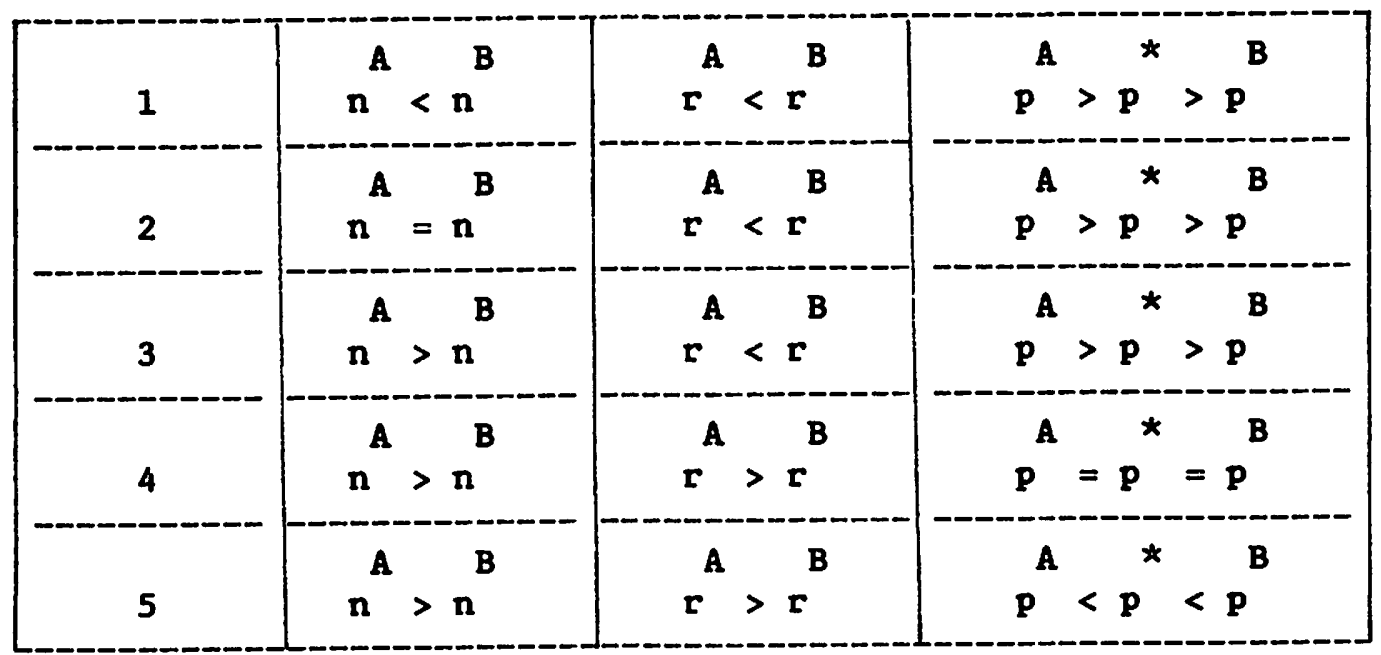

The first case results from country $A$ having a relatively lower rate of population growth than country B. This, together with the lower rate of depreciation, yields a lower steady-state return on capital and hence a higher autarkic relative price. A will therefore demand more education per capita 
than $B$ and export $X$, the capital-intensive good. As time progresses, B will grow increasingly large and the terms of trade for A will continue to improve, converging asymptotically on $p^{B}$.

Case 2, where the countries have the same rate of population growth, has already been discussed at some length and so is ignored.

In the third case, country A's population grows relatively faster, but not sufficiently fast to offset the difference in the countries' rates of capital depreciation. Hence the return on capital in A will be less than that in $B$ and A will, again, have a lower autarkic relative price for the capital-intensive good. A will therefore export $X$ but, as its population grows relatively more quickly, it will experience a secular deterioration in its terms of trade. It is uncertain as to which of the countries will have the higher per capita investment in education.

In case 4 , the rate of population growth in $A$ is just sufficiently greater than that of B so that both countries have the same rate of return on capital. Their autarkic prices will be the same and so there will be no trade at any point in time. Production in the two countries will not be the same because the countries' rates of interest will differ. Differentiating equation (29), holding $r$ constant yields:

$$
\frac{d k_{E}}{d n} \quad d r=0=\frac{2 n}{h^{\prime \prime}\left[k_{E}\right] w[r]}<0,
$$

the faster growing population (A) will acquire less human capital per capita. From equation (24), agents in country A will then have lower lifetime levels of per-capita consumption and hence, because their interest rate is higher, lower per-capita utility. 
Country $A$ in case 5 seems to have the attributes associated with many less devloped countries, while B would correspond to an industrialized nation. A's faster rate of population growth outweighs its relatively smaller rate of depreciation such that it has a higher return on capital than does country B. As a result, country A has a lower autarkic relative price and the pattern of trade will be different from that of the previous cases. A will import $X$, the capital-intensive good though, because it is growing more rapidly, A's terms of trade will deteriorate. As in case 4 , the per-capita investment in education will be less in country $A$ than that in $B$.

Now relax the assumption of myopia and let the agents accurately predict the changes in the terms of trade. The terms of trade will only be changing over time when countries are not in the steady state (cases 1,3 , and 5 ). The impact on a country of expected relative price changes will depend largely on the pattern of production and trade.

In cases 1 and 3 country $A$ is specialized in the production of the capital good, $X$, while country $B$ specializes in $X$ production in case 5 . The returns on investments in human and physical capital are independent of the future relative price of the consumption good. From the first-order conditions, equations (18) and (19), an agent's investments will depend crucially on the rate of interest. $R^{t}$ is set to clear the credit market and will adjust should an expected change in the future price ratio lead to an alteration in the intertemporal allocation of consumption expenditures. Clearly, what happens depends on the characterization of preferences. Suppose the utility function is Cobb-Douglas, then the elasticity of substitution between consumption in the two periods of an agent's life is unity and the 
expenditure shares on consumption in each period are fixed and, hence, changes in expected prices will not affect the current demand for consumption. The credit market would therefore continue to clear at the same rate of interest, irrespective of expectations. " A country whose terms of trade improve over time (A for case 1 and B for case 5) will enjoy ever-increasing consumption--it becomes relatively smaller than its trading partner and captures more and more of the gains from trade. In case 3 , country A's more rapidly growing population results in a secular deterioration in its export prices and hence, though expenditure levels remain constant, consumption declines over time as the gains from trade diminish.

In case 5, country $A$ is specialized in the production of the consumer good, $Y$, as is country $B$ in cases 1 and 3 . Current investments must take into account the expected appreciations or depreciations in the relative price of that good. It was shown in section 4 that physical and human capital accumulation, for a country specialized in the production of good $Y$, is greater the higher is the steady-state relative price of that good. Now, consider the impact of an expected change in the terms of trade of the Y-producer.

In cases 1 and 5 , the relative price of good $Y$ falls over time. With an unchanged market interest rate, the expected future return on physical capital will fall and so, from equation (18), the investment in physical capital must fall. The future wage will decrease, both because of the price decrease and because production will become relatively less capital intensive, and this will induce a fall in the investment in human capital [using equation (19)]. Expected labour income decreases, reducing consumption demand which, if the 
elasticity of substitution is at least unity, will definitely reduce current consumption expenditure. Thus all the elements of the demand for credit fall with anticipated relative price decreases and so the interest rate must fall to clear the market. The impact on the levels of human and physical capital in the resulting equilibrium is uncertain. Similarly in case 3 , in which B's terms of trade are expected to improve, the market rate of interest will rise, but little else can be determined without a full specification of the model.

Thus expected changes in the terms of trade may have little affect on accumulation in countries producing the capital good, while having uncertain effects on the investment of those producing the consumer good.

\section{Summary and Conclusions}

This paper has developed a general equilibrium model of international trade in which the levels of education and quantities of physical capital acquired by agents are determined optimally.

The model has many of the characteristics of the familiar Ricardian framework. In autarky, production is determined entirely by the economy's technology--its production functions and rate of physical capital depreciation--while a country that trades will specialize in the production of only one of the final goods. As international prices change, the levels of investment in both physical and human capital will change. The higher the relative price of the consumption good, the greater the investment in the production of the good. The more rapidly a country's population expands, the lower the per capita investment in education.

Countries with identical production functions will find cause to trade if their rates of physical capital depreciation differ. The country whose 
capital depreciates less quickly will not only acquire more of it, but will also choose to be better educated and will specialize in the production of the relatively capital-intensive good.

Countries with different rates of population growth may choose to trade, the pattern of trade being influenced by differences in both the rates of population growth and the rates of physical capital depreciation. For countries that are otherwise identical, the one with the more rapidly expanding population will specialize on the labour-intensive good, will invest less in education, and will experience a secular deterioration in its terms of trade. Thus demographic differences may account for some less developed countries' specialization in primary production as well as for continued worsening in their world trading positions. 


\section{Footnotes}

*

The author thanks Jim Davies, Jim Melvin, and Elias Dinopoulos for comments and suggestions and acknowledges support for this research from the Social Sciences and Humanities Research Council of Canada and the Sloan Foundation.

1 An alternative modelling could permit students to choose between spending their time working or learning. As all agents are identical, and the focus of this paper is on human capital accumulation, the resulting equilibrium in which all students invest in education would be qualitatively identical to that discussed here.

The term "government" is, perhaps, a misnomer, in that the agency under consideration here has no active policy role. A more accurate sense of its activities might be conveyed by institutional designations of, for example, a savings and loan association" (for the U.S.) or a "building society" (for the U.K.).

Were students given the choice of working or learning [see footnote 1], then the total cost of investment in human capital, including the foregone wage, must be less than the present value of the return to education:

$$
w^{t}+r^{t} k_{E}^{t} \leq \frac{h\left[k_{E}^{t}\right] w^{t+1}}{\left(1+R^{t}\right)}
$$

4 Were the elasticity of substitution greater (less) than one then a rise in the expected future price will result in increased (reduced) demand for consumption borrowing [for a full discussion of this, see Atkinson and Stiglitz (1980)]. The interest rate would then have to rise (fall) to clear the credit market, which would result in reduced (increased) investment in physical and human capital. 


\section{References}

Atkinson, Anthony B., and Joseph E. Stiglitz, (1980), Lectures on Public Bconomics, (HcGraw-Hill: New York).

Diamond, Peter A., (1965), "National Debt in a Neoclassical Growth Model," American Bconomic Review, 55 (December): 1126-50.

Dinopoulos, Elias, and Ian Wooton, (1986), "International Trade and the Acquisition of Skills," CSIER Working Paper No. 8606C, University of Western Ontario.

Oniki, H., and H. Uzawa, (1965), "Patterns of Trade and Investment in a Dynamic Model of International Trade," Review of Bconomic studies, XXXII (January): 15-38.

Phelps, Edmund S., (1961), "The Golden Rule of Accumulation: A Fable for Growthmen," American Bconomic Review, 51 (September): 638-42. Reprinted in Edmund S. Phelps, (1980), studies in Macroeconomic Theory, Volume 2, Redistrubution and Growth, (Academic Press: New York).

Samuelson, Paul A., (1958), "An Exact Consumption Loan Model of Interest with or without the Social Contrivance of Money," Journal of Political Economy, 66 (December): 467-482.

Stiglitz, Joseph E., (1970), "Factor Price Equalization in a Dynamic Economy," Journal of Political Bconomy, 78 (May/June): 456-488.

Wan, Henry Y., Jr., (1971), Bconomic Growth, (Harcourt Brace Jovanovich: New York). 


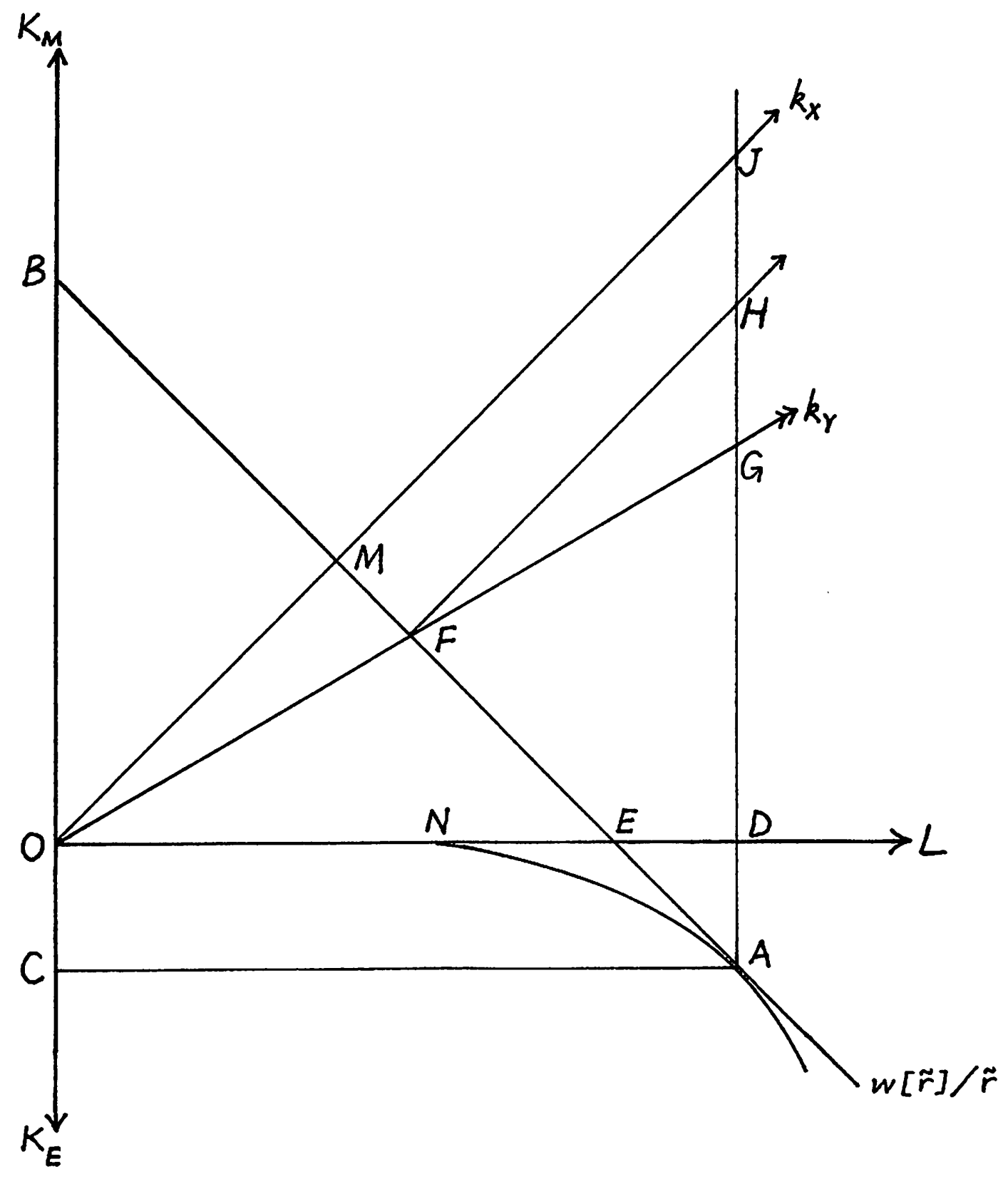

Figure 1 


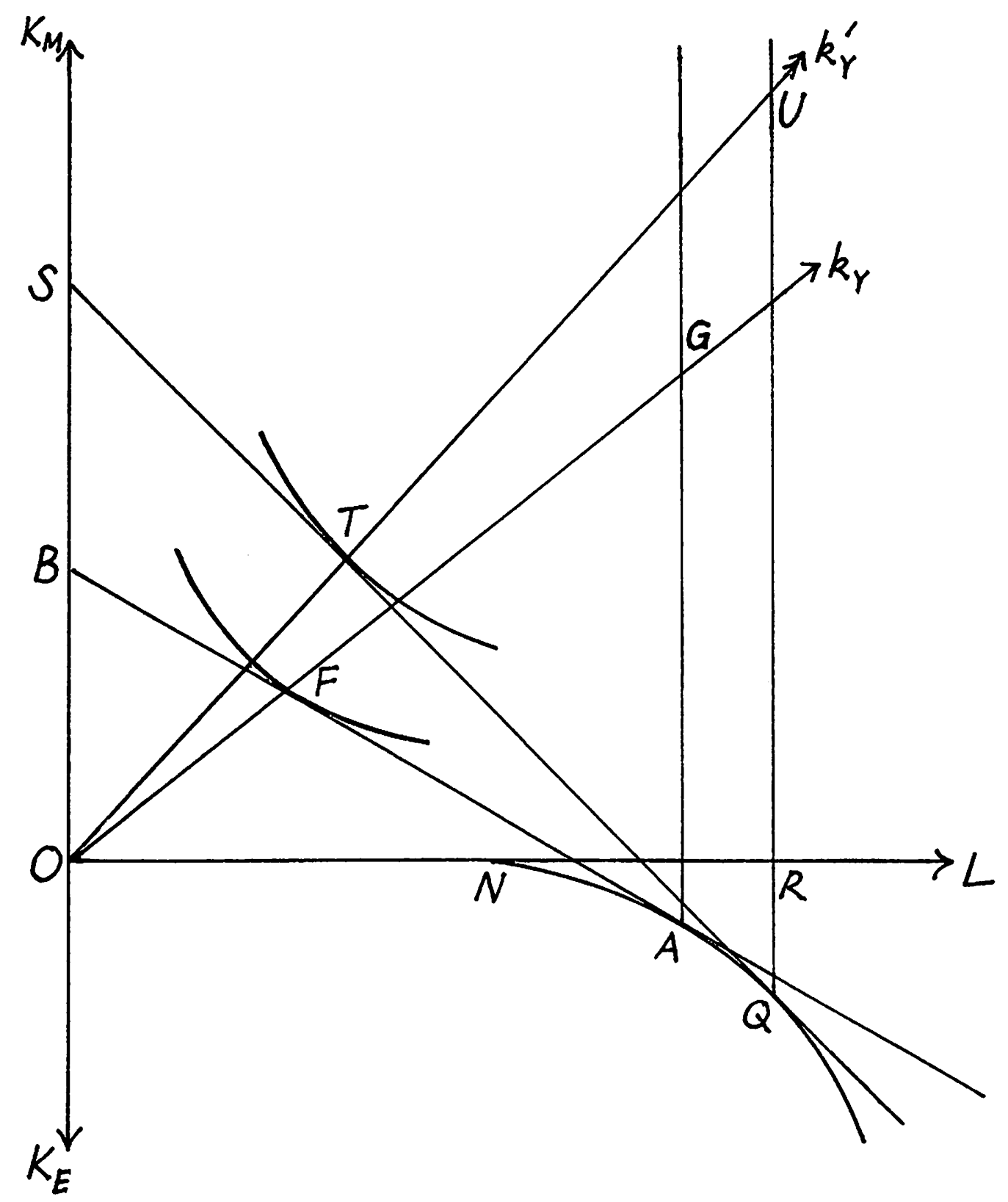

Figure 2 


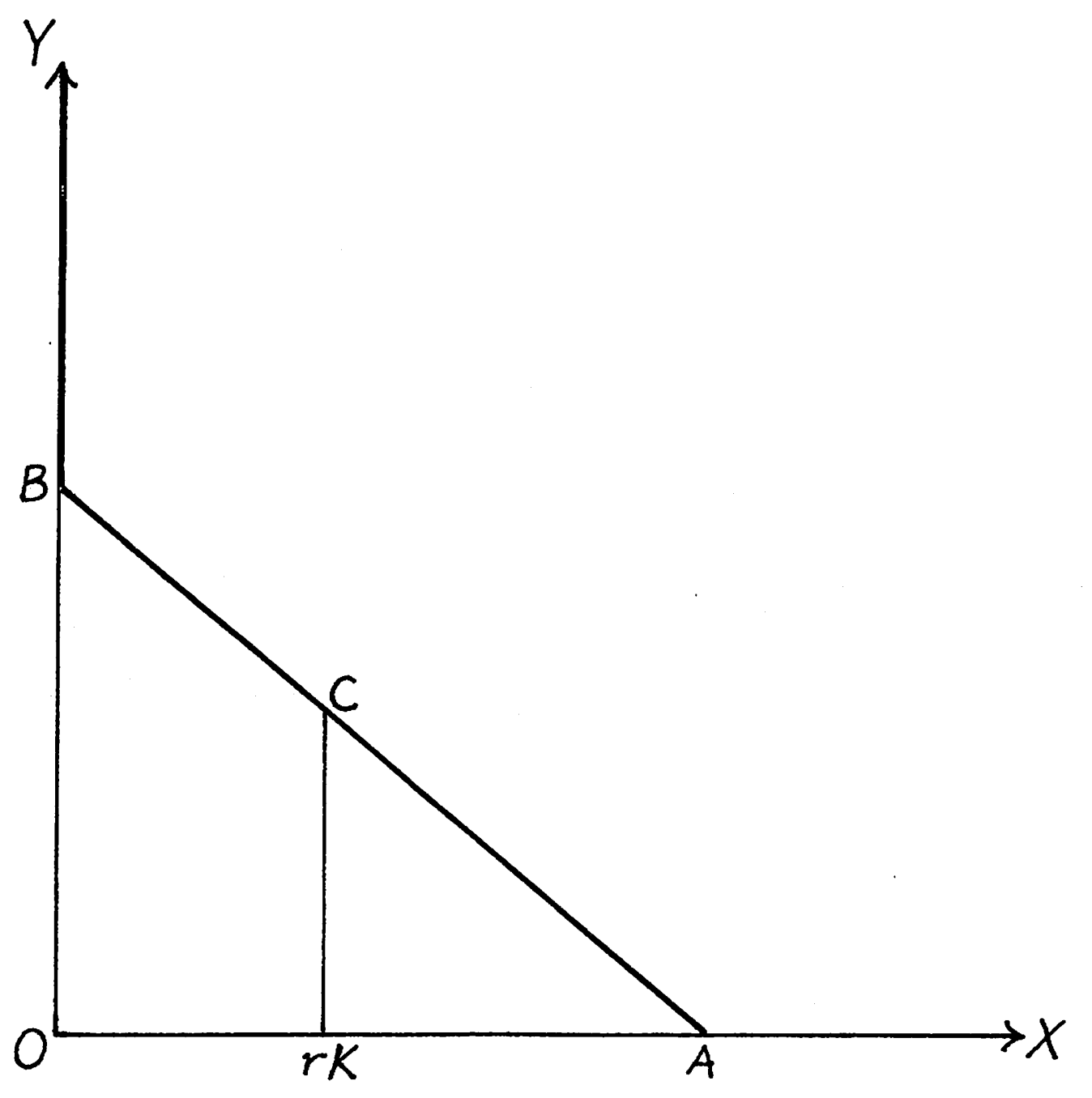

Figure 3 
8401C Harrison, Glenn W. and Manning, Richard. BEST APPROXIMATE AGGREGATION OF INPUT-OUTPUT SYSTEMS.

8402C Parkin, Michael. CORE INFLATION: A REVIEH ESSAY.

8403C Blomqq1st, Ảke, and McMahon, Gary. SIMULATING COMRRICAL POLICY IN A SMALL, OPEN DUAL ECONOMY WITH URBAN UNEMPLOYMENT: A GENERAL EQUILIBRIUM APPROACH.

8404C Nonnacott, Ronald. THE THEORY OF TRADE DISCRIMINATION: THE IIIRROR IMAGE OF VINERIAN PREFERENCE THEORY?

84050 Whalley, John. IMPACTS OF A $50 \%$ TARIFF REDUCTION IN AN EIGHT-REGION GLOBAL TRADE MODEL.

84060 Harrison, Glenn W. A GENERAL EQUIIIBRIUM ANALYSIS OF TARIFP REDUCTIONS.

$8407 C$ Horstmann, Ignatius and Markusen, James R. STRATEGIC INVESTMENTS AND . THE DEVELOPMENT OF MULTINATIONALS.

8408C Gregory, Allan $\omega$. and McCurdy, Thomas H. TESTING THE UNBIASEDNESS HYPOTHESIS IN THE FORIARD FOREIGN EXCHANGE MARKET: A SPECIFICATION ANALYSIS.

8409C Jones, Ronald $\%$, and Klerzkowsk1, Henryk. NEIGHBORHOOD PRODUCTION STRUCTURES WITH APPLICATIONS TO THE THEORY OF INTERNATIONAL TRADE.

$8410 \mathrm{C}$ Weller, Paul and Yano, Makoto. THE ROLE OF FUTURES MARKETS IN INTERNATIONAL TRADE: A GENERAL EỌUILIBRIUM APPROACH.

$8411 \mathrm{C}$ Brecher, RIchard A. and Bhagwat1, Jagdish N. VOLUNTARY EXPORT RESTRICTIONS VERSUS IMPORT RESTRICTIONS: A WELFARE-THEORETIC COMPARISON.

8412C Ethier, W11fred J. ILLEGAL IRMIGRATION.

8413C Eaton, Jonathon and Gene M. Grossman. OPTIMAL TRADE AND INDUSTRIAL POLICY UNDER OLIGOPOLY.

8414C Hooton, Ian. PREFERENTIAL TRADING AGREEMENTS - A 3xn MODEL.

8415C Parkin, Michael. DISCRIMINATJNG BETWEEN KEXNESIAN AND CLASSICAL THEORIES OF THE BUSINESS CYCLE\& JAPAN 1967-1982

8416C Deardorff, Alan V. FIRless FIRwoes: HOW PREFERENCES CAN INTERFERE WITH THE THEOREMS OF INTERNATIONAL -TRADE.

8417C Greenwood, Jeremy. NONTRADED GOODS, THE TRADE BALANCE, AND THE BALANCE OF PAYRENTS. 
$8418 \mathrm{C}$ Blomqvist, Ake and Sharif Mohammad. CONTROLS; CORRUPTION, AND COMPETITIVE RENT-SEEKING IN LDCS.

8419 C Gossman, Herschel I. POLICY, RATIONAL EXPECTATIONS, AND POSITIVE ECONOMIC ANALYSIS.

8420C Garber, Peter M. and Robert G. King. DEEP STRUCTURAL EXCAVATION? A CRITIOUUE OF EULER EQUATION METHODS.

$8421 \mathrm{C}$ Barro, Robert J. THE BEHAVIOR OF U.S. DEFICITS.

8422C Persson, Torsten and Lars E.0. Svensson. INTERNATIONAL BORROWING AND TIME-CONSISTENT FISCAL POLICY.

$8423 \mathrm{C}$ Obstfeld Maurice. CAPITAL CONTROLS, THE DUAL EXCHANGE RATE, AND DEVALUATION.

$8424 \mathrm{C}$ Kuhn, Peter. UNION PRODUCTIVITY EFFECTS AND ECONOMIC EFFICIENCY.

8425C Hamilton, Bob and John Whalley. TAX TREATMENT OF HOUSING IN A DYNAMIC SEỌUENCED GENERAL EOUUILIBRIUM MODEL.

$\because 426 \mathrm{C}$ Hamilton, Bob, Sharif Mohanmad, and John Whalley. RENT SEEKING AND THE NORTH-SOUTH TERMS OF TRADE.

8427C Adams, Charles and Jeremy Greenwood. DUAL EXCHANGE RATE SYSTEMS AND CAPITAL CONTROLS: $\Lambda$ N INVESTIGATION.

8428 Loh, Choon Cheong and Michael R. Veall. A NOTE ON SOCIAL SECURITY AND PRIVATE SAVINGS IN SINGAPORE.

8429

Whalley, John. REGRESSION OR PROCRESSION: THE TAYING OUUESTION OF INCIDENCE ANALYSIS.

3430 Kuhn, Peter. WAGES, EFFORT, AND INCENTIVE-COMPATIBILITY IN LIFE-CYCLE EMPLOYMENT CONTRACTS.

8431 Greenwood, Jeremy and Kent P. Kimbrough. AN INVESTIGATION IN THE THEORY OF FOREIGN EXCHANGE CONTROLS.

8432 Greenwood, Jeremy and Kent-P. Kimbrough. CAPITAL CONTROLS AND THE INTERNATIONAL TRANSMISSION OF FISCAL POLICY.

8433 : Nguyen, Trien Trien and John Whalley. EṇILIBRIUM UNDER PRICE CONTROLS WITH ENDOGENOUS TRANSACTIONS COSTS.

Adams, Charles and Russell S. Boyer. EFFICIENCY AND A SIMPLE MODEL OF EXCHANGE RATE DETERMINATION. 
8435 Kuhn, Peter. UNIONS, ENTREPRENEURSHIP, AND EFFICIENCY.

8436 Hercowitz, Zv1 and Efraim Sadka, ON OPTIMAL CURRENCY. SUBSTITUTION POLICY AND PUBLIC PINANCE.

8437 Lenjosek, Gordon and John Whalley, POLICY EVALUATION IN A SMALL OPEN PRICE TAKING ECONOMY: CANADIAN ENERGY POLICIES.

8438 Aschauer, David and Jeremy Greenwood. MACROECONOMIC EFFECTS OF FISCAL POLICY.

8439C Hercowitz, Zv1. ON THE DETERMINATION OF THE EXTERNAL DEBT: THE CASE OF ISRAEL.

8440C Stern, Robert M. GLOBAL DIMENSIONS AND DETERMINANTS OF INTERNATIONAL TRADE AND INVESTMENT IN SERVICES.

$8441 \mathrm{C}$ Deardorff, Alan V. COMPARATIVE ADVANTAGE AND INTERNATIONAL TRADE AND INVESTMENT IN SERVICES.

8442C Daly, Donald J. TECHNOLOGY TRANSFER AND CANADA'S COMPETITIVE PERFORMANCE.

8443C Grey, Rodney de C. NEGOTIATING ABOUT TRADE AND INVESTMENT IN SERVICES.

$8444 C$ Grossman, Gene M. and Carl Shapiro. NORMATIVE ISSUES RAISED BY INTERNATIONAL TRADE IN TECHNOLOGY SERVICES.

8445C Chant, John F. THE CANADIAN TREATMENT OF FOREIGN BANKS: A CASE STUDY IN THE WORKINGS OF THE NATIONAL TREATMENT APPROACH.

8446C Aronson, Jonathan D. and Peter F. Cowhey. COMPUTER, DATA PROCESSING, AND COMMUNICATION SERVICES.

8447C Feketekuty, Geza.- NEGOTIATING STRATEGIES FOR LIBERALIZING TRADE AND INVESTMENT IN SERVICES.

8448C Harrison, Glenn, W. and E.E. Rutstrom. THE EFFECT OF MANUFACTURING SECTOR PROTECTION ON ASEAN AND AUSTRALIA: A GENERAL ENUUILIBRIUM ANALYSIS. 
8501C Greenwood, Jeremy and Kent P. Kimbrough. FOREIGN EXCHANGE CONTROLS IN A BLACK MARKET ECONOMY.

8502C Horstmann, Ignatius and James R. Markusen. UP YOUR AVERAGE COST CURVE: INEFFICIENT ENTRY AND THE NEW PROTECTIONISM.

8503C Gregory, Allan W. TESTING INTEREST RATE PARITY AND RATIONAL EXPECTATIONS FOR CANADA AND THE UNITED STATES.

$8504 \mathrm{C}$ Kuhn, Peter and Ian Hooton. INTERNATIONAL FACTOR MOVEMENTS IN THE PRESENCE OF A FIXED FACTOR.

8505C Wong, Kar-yiu. GAINS FROM GOODS TRADE AND RACTOR MOBILITY.

8506C Heller, Paul and Mako to Yano. FUTURES MARKETS, REAL INCOME, AND SPOT PRICE VARIABILITY: A GENERAL EỌUIL IBRIUM APPROACH.

8507C Diewert, W.E. THE EFFECTS OF AN INNOVATION: A TRADE THEORY APPROACH.

8508C Ethier, Wilfred J. POREIGN DIRECT INVESTMENT AND THE MULTINATIONAL FIRM.

8509C Dinopoulos, E11as. INSIDE THE BLACK BOX: (IN)TANGIBLE ASSETS, INTRA-INDUSTRY INVESTMENT AND TRADE.

8510C Jones, Rlchard, John Whalley, and Randall H1gle. REGIONAL IMPACTS OF TARIFFS IN CANADA: PRELIMINARY RESULTS FROM A SMALL DIMENSIONAL NUMERICAL GENERAL EOUUIL IBRIUM MODEL.

8511C Whalley, John. HIDDEN CHALLENGES IN RECENT APPLIED GENERAL EQUILIBRIUM EXERCISES.

3512C Smith, Bruce. SOME COLONIAL EVIDENCE ON THO THEORIES OF MONEY: MARYLAND AND THE CAROLINAS.

9513C Grossman, S.J., A. Melino, and R.J. Shiller. ESTIMATING THE CONTINUOUS TIME CONSUMPTION BASED ASSET PRICING MODEL.

8514C Romer, Paul R. TAX EFFECTS AND TRANSACTION COSTS FOR SHORT TERM MARKET DISCOUNT BONDS. .

8515C McCallum, Bennett T. ON CONSEỌUENCES AND CRITJCISMS OF MONETARY TARGETING.

8516C Dinopoulos, Elias and Ian Wooton. A NORTH-SOUTH MODEL OF INTERNATIONAL JUSTICE.

8517C Huffman, Gregory W. A DYNAMIC EQUILIBRIUM MODEL OF ASSET PRICES AND TRANSACTION VOLUME.

8518C Huffman, Gregory W. AN ALTERNATIVE VIEW OF OPTIMAL SEIGNIORAGE.

8519C Huffman, Gregory W. ASSET PRICING WITH HETERGENEOUS ASSETS. 
8520C Hercowitz, Zvi. THE REAL INTEREST RATE AND AGGREGATE SUPPLY.

8521C Davies, James and Michael Hoy. COMPARING INCOME DISTRIBUTIONS UNDER AVERSION TO DOWNSIDE INEQUALITY.

8522C Nguyen, Trien $T$. and John Whalley. COEXISTENCE OF EQUIIIBRIA ON BLACK AND WHITE MARKETS.

8523C Clarete, Ramon and John Whalley. INTERACTIONS BETWEEN TRADE POLICIES AND DOMESTIC DISTORTIONS: THE PHILIPPINE CASE.

8524C Hamilton, Bob, Sharif Mohammad, and John Whalley. APPLIED GENERAL EQUILIBRIUM ANALYSIS AND PERSPECTIVES ON GROWTH PERFORMANCE.

8525C Huffman, Gregory $W$. THE LAGGED EFFECTS OF POLICY ON THE PRICE LEVEL.

8526C Laldler, David. FISCAL DEFICITS AND INTERNATIONAL MONETARY INST ITUTIONS.

8527C Goodfriend, Marvin. MDNETARY MYSTIQUE: SECRECY AND CENTRAL BANKING.

8528C Nguyen, Trien $\mathrm{T}$. and. John Whalley. GENERAI EQUILIBRIUM ANALYSIS OF PRICE CONTROLS A TWO-SECTOR COMPUTATIONAL APPROACH.

8529C Heckman, James $J$. and $\mathrm{V}$. Joseph Hotz. AN INVESTIGATION OF THE LABOR MARKET EARNINGS OF PANAMANIAN MALES: EVALUATING SOURCES OF INEQUALITY.

8530C Greenwood, Jeremy and Gregory W. Huffman. A DYNAMIC EQUILIBRIUM MODEL OF INFLATION AND UNEMPLOYMENT.

8531C Freeman, Scott. INSIDE MONEY, MONETARY CONTRACTIONS, AND WELFARE.

8532C Paderanga, Cayetano Jr. and Ian Wooton. A POSITIVE VIEW OF INFANT INDUSTRIES.

8533C St-Hilaire, France and John Whalley. A MICROCONSISTENT DATA SET FOR CANADA FOR USE IN REGIONAL GENERAL EQUIIIBRIUM POLICY ANALYSIS.

8534C Whalley, John. OPERATIONALIZING WALRAS: EXPERIENCE WITH RECENT APPLIED GENERAL EQUILIBRIUM TAX MODELS .

8535C Melvin, James R. THE GENERAL NON-EQUIVALENCE OF. TARIFFS AND IMPORT QUOTAS. 
8601C Greenwood, Jeremy and R. Preston McAfee. EXTERNALITIES AND ASYMAETRIC INFORMATION.

8602C Dinopoulos, Elias and Mordecha1 E. Krelnin. IMPORT OUUOTAS AND VERS: A COMPARATIVE ANALYSIS IN A THREE-COUNTRY FRAMEWORK.

8603C Clarete, Ramon and John Whalley. COMPARING THE MARGINAL WELFARE COSTS OF COMMODITY AND TRADE TAXES.

8604C Wigle, Randy. CANADIAN TRADE LIBERALIZATION: SCALE ECONOMIES IN A GLOBAL CONTEXT.

8605C Parkin, Michael. DOMESTIC MONETARY INSTITUTIONS AND FISCAL DEFICITS.

8606C Dinopoulos, Elias and Ian Wooton. INTERNATIONAL TRADE AND THE ACQUISITION OF SKILLS.

8607C Kawasaki, Selichi and John McMillan. THE DESIGN OF CONTRACTS: EVIDENCE FROM JAPANESE SUBCONTRACTING.

8608C Williamson, stephen D. LIQUIDITY, BANKING, AND BANK FAILURES.

8609C Grossman, Gene M. and Carl Shapiro. COUNTERFEIT-PRODUCT TRADE.

8610C Deardorff, Alan V. WHY DO GOVERNMENTS PREFER NONTARIFF BARRIERS?

$8611 \mathrm{C}$ Horstmann, Ignatius and James R. Markusen. LICENSING VERSUS DIRECT INVESTMENT: A MODEL OF INTERNALIZATION BY THE MULTINATIONAL ENTERPRISE.

8612C Thursby, Jerry G. and Marie C. Thursby. BILATERAL TRADE FLOWS, THE LINDER HYPOTHESIS, AND EXCHANGE RISK.

8613C Clarete, Ramon and John Whalley. EQUIIIBRIUM IN THE PRESENCE OF FOREIGN EXCHANGE PREMIA.

8614C Wooton, Ian. TOWARDS A COMMON MARKET: FACTOR MOBILITY IN A CUSTOMS UNION.

8615C St-Hilaire, France and John Whalley. SOME ESTIMATES OF TRADE FLOWS IN BANKING SERVICES.

8616C Evenson, Robert E. and Cayetano Paderanga Jr. RURAL LABOUR MARKETS, TRANSACTION COST AND FERTILITY.

8617C Fried, Joel and Peter Howitt. FISCAL DEFICITS, INTERNATIONAL TRADE AND WELFARE.

8618C Trela, Irene, John Whalley, and Randy Wigle. INTERNATIONAI TRADE IN AGRICULTURE: DOMESTIC POLICIES, TRADE CONFLICTS, AND NEGOTIATING OPTIONS. 
8619C Markusen, James R. and Anthony J. Venables. TRADE POLICY WITH INCREASING RETURNS AND IMPERFECT COMPETITION: CONTRADICTORY RESULTS FROM COMPETING ASSUMPTIONS.

8620C Hunter, Linda and James R. Narkusen. PER-CAPITA INCOME AS A DETERMINANT OF TRADE.

8621C Jones, Rich and John Whalley. A CANADIAN REGIONAL GENERAI EQUILIBRIUM MODEL AND SOME APPLICATIONS.

8622C Freeman, Scott, and Gregory W. Huffman. INSIDE MONEY, OUTPUT, AND CAUSALITY.

8623C Hamilton, Colleen, and John Whalley. DEALING NITH THE NORTH: DEVELOPING COUNTRIES AND GLOBAL TRADE NEGOTIATIONS.

8624C Williamson, Stephen D. LAISSEZ FAIRE BANKING AND CIRCULATING MEDIA OF EXCHANGE.

8625C Whalley, John. WHAT HAVE WE LEARNED FROM GENERAL EQUILIBRIUM TAX POLICY MODELS?

8626C Bhatia, Kul B. SHORT RUN AND LONG RUN IN THE THEORY OF TAX INCIDENCE.

8627C Jones, Rich, and John Whalley. REGIONAL EFFECTS OF TAXES IN CANADA: AN APPLIED GENERAL EQUILIBRIUM APPROACH.

8628C Nguyen, Trien T., and John Whalley. GENERAL EQUILIBRIUM WORLD TRADE UNDER BILATERAL QUOTAS.

8629C Clarete, Ramon L., and James A. Roumasset. THE RELATIVE WELFARE COST OF INDUSTRIAL AND AGRICULTURAL PROTECTION POLICIES USING PHILIPPINE DATA. 
8701C McMillan, John, John Whalley, and Zhu Li Jing. INCENTIVE EFFECTS OF PRICE RISES AND PAYMENT-SYSTEM CHANGES ON CHINESE AGRICULTURAL PRODUCTIVITY GROWTH.

8702C Wooton, Ian. CAPITAL, SKILLS, AND INTERNATIONAL TRADE. 